\title{
TRADISI INTELEKTUAL ACEH DI DAYAH TANOH ABEE DAN DAYAH RUHUL FATA
}

\author{
Acehnese Intellectual Tradition \\ in Dayah Tanoh Abee and Dayah Ruhul Fata
}

\author{
Fakhriati \\ Puslitbang Lektur dan Khazanah Keagamaan \\ Badan Litbang dan Diklat Kementerian Agama RI \\ Jl. M.H. Thamrin No.6 lt.18 Jakarta Pusat \\ Email: fakhriati70@gmail.com dan fakhri_ati@yahoo.co.uk
}

Naskah diterima tanggal 18 Maret 2014. Naskah direvisi tanggal 02 Juli 2014. Naskah disetujui tanggal 7 Juli 2014

\begin{abstract}
Abstrak
Sejak Islam masuk ke wilayah Aceh, dilanjutkan dengan masa kejayaan, penjajahan, dan kemerdekaan, para ulama Aceh telah mengisi warna sejarah tradisi intelektual dengan berbagai tulisan tangannya yang sekarang sebagiannya masih disimpan baik di dayah (pesantren) maupun di masyarakat. Tradisi intelektual di Aceh telah berkembang secara dinamis dalam menyahuti perkembangan zamannya. Dua dayah, Tanoh Abee dan Ruhul Fata, misalnya, menyimpan karya-karya ulama yang dapat dilihat perkembangan tradisi intelektual dari periode ke periode. Tulisan ini menganalisis karya ulama yang disimpan di Dayah Tanoh Abee dan karya ulama yang ada di Dayah Ruhul Fata untuk melihat sejauhmana tradisi intelektual berkembang di kedua dayah ini pada masa silam dan masa sekarang. Penelitian ini dilakukan dengan menggunakan pendekatan filologi dan sejarah, serta mengumpulkan data melalui eksplorasi, observasi, dan inventarisir karya-karya ulama di dua dayah tersebut. Hasil penelitian menunjukkan bahwa terjadi kesinambungan tradisi intelektual yang cukup dinamis dari abad ke 17 hingga 20 di wilayah ini dan pengadopsian tradisi penulisan dari naskah Arab Timur Tengah.
\end{abstract}

Kata kunci: ulama, dayah, tradisi penulisan, naskah

\begin{abstract}
Since Islam coming to Aceh, continued with its gold era, colonized era, and freedom era, Acehnese ulamas had colored historical intellectual tradition approved by their hand writings collected by both traditional Islamic school (dayah) and local society. This tradition developed dynamically because of time and period. This article tries to analyse ulamas works kept in Dayah Tanoh Abee and the works of ulama in Dayah Rahul Fata in Aceh Besar Regencies, and aims at discussion on the extent of intellectual tradition developed and changed in this two places from $17^{\text {th }}$ to $20^{\text {th }}$ centuries. This research is performed by using philological and historical approach, and the data is collected through exploration, direct observation, and invetarisation on ulamas' writing. From this research, it can be argued that intellectual tradition has dinamically developed and also adopted writing tradition of Arabic manuscripts from Middle East.
\end{abstract}

Keywords: ulama, dayah, writing tradition, manuscript

\section{PENDAHULUAN}

$\mathrm{A}$ ceh adalah salah satu wilayah Nusantara, khususnya Indonesia, merupakan wilayah pertama yang pernah disentuh Islam. Teori ini didukung oleh adanya berbagai tulisan hasil penelitian dan hasil seminar yang menyatakan bahwa salah satu daerah di Aceh, tepatnya Peureulak sebagai tempat pertama masuknya Islam sekitar abad ke-9 M. Daerah ini menjadi tempat kunjungan pedagang dari Timur Tengah, yaitu Arab dan Persia, serta dari Gujarat untuk 
membeli lada dan hasil rempah-rempah lainnya. Bermula dari daerah ini, lalu tumbuhlah kerajaan Islam pertama dan kemudian diikuti oleh kerajaan Islam Pasai (Tulisan-tulisan tentang sejarah Aceh, seperti Aceh Sepanjang Abad dan Tarich Atjeh, serta isi manuskrip di antara adalah Hikayat Raja Pasai memberikan informasi tentang Perlak sebagai daerah awalnya masuk Islam. Selain itu, hasil seminar International yang diadakan oleh IAIN Ar-Raniry pada tanggal 30 Oktober 2010 juga telah membahas panjang lebar tentang masuknya Islam di wilayah ini).

Pada abad ke-17 M Islam sempat berjaya dan mencapai momentumnya di wilayah ini dengan lahirnya ulama-ulama terkenal, seperti Hamzah Fansuri dan Ar-Raniry. Mereka telah mengabdikan dirinya dan kecerdasannya untuk kepentingan umat dan negara. Mereka telah menjadi qadhi sebagai tumpuan kerajaan dalam menyelesaikan masalahmasalah kenegaraan. Mereka juga berdakwah kepada umat dengan mengembangkan ajarannya lewat tulisan-tulisan mereka dan mendidik para muridnya lewat dayah (pesantren), yang kemudian melahirkan para ulama terkenal lainnya.

Pada masa kejayaannya, Islam di wilayah ini menjadi tumpuan perkembangan Islam di masa-masa sesudahnya dan sangat mempengaruhi generasi selanjutnya. Pada abad ke-18 M dan 19 $M$ bisa dikatakan sebagai abad yang suram bagi kehidupan masyarakat Aceh karena kemunduran kerajaan Aceh dan berkuasanya penjajah di wilayah ini. Namun demikian, kemunduran di bidang politik dan kekuasaan ternyata tidak sangat berpengaruh negatif terhadap perkembangan intelektualitas keagamaan. Di berbagai dayah, semangat juang untuk mempertahankan agama, negara, dan keturunan mereka, dengan cara yang telah diwariskan leluhur mereka, yaitu berdakwah bil lisan dan bil kitabah tetap bertahan. Dayah terus berkembang di mana-mana, tulisan para ulama juga tidak merosot, bahkan bertambah banyak dalam menyahuti perkembangan zamannya.

Dari periode ke periode, dayah-dayah semakin banyak bertebaran di Aceh, sehingga bagi masyarakat Aceh masih tertanam persepsi bahwa di dayahlah tempat mendidik umatnya bahagia dunia dan akhirat. Salah satu dayah yang dapat dijadikan contoh nyata untuk melihat perkembangannya dari zaman ke zaman adalah Dayah Tanoh Abee. Dayah ini didirikan sejak abad ke-17 M oleh seorang murid dari Abdurrauf Singkil, yaitu Syekh Nayyan yang dikatakan berasal dari Baghdad, Irak. Dayah ini terus berkembang hingga sekarang dan menyimpan sejumlah kitab-kitab hasil karya ulama setempat dan ulama dari luar dayah tersebut. Di antara tokoh-tokoh yang cukup produktif dalam menulis adalah Teungku Abdul Wahab Dayah Tanoh Abee yang dikenal juga sebagai pahlawan dalam membela Aceh melawan penjajah Belanda.

Latar belakang di atas menjadi landasan untuk melakukan penelitian di wilayah Aceh, sebagai wilayah yang cukup berpotensi menyimpan sejumlah karya-karya ulama setempat. Selanjutnya, berdasarkan kesediaan waktu yang diperuntukkan untuk penelitian ini, area penelitian dipersempit kepada lokasi Aceh Besar saja dengan alasan; pertama, kedua dayah ini muncul dalam waktu dan periode yang berbeda. Dayah Tanoh Abee muncul pada abad ke-17 M dan Dayah Ruhul Fata muncul pada abad ke-20 M. Perbedaan waktu seperti ini diharapkan dapat mencerminkan kriterianya masing-masing yang membedakan satu sama lain karena dipengaruhi waktu. Kedua, kedua dayah ini memiliki dan menyimpan sejumlah karya ulama baik ulama setempat maupun ulama di luar dayah tersebut.

Tulisan ini mencoba menganalisis karya ulama yang disimpan di Dayah Tanoh Abee dan karya ulama di Dayah Ruhul Fata untuk melihat sejauhmana tradisi intelektual berkembang di kedua dayah ini pada masa silam dan masa sekarang. Selanjutnya dituangkan ke dalam rincian permasalahan yang akan dijawab dalam penelitian ini, yaitu tentang deskripsi, isi singkat, dan alasan yang melatarbelakangi hadirnya karyakarya tersebut. Sedangkan tujuan dari penelitian ini adalah untuk mendeskripsi, mengungkapkan isi singkat, dan menjelaskan hal yang berkaitan dengan penulisan karya-karya ulama yang terdapat di dua Dayah tersebut. Dengan demikian tradisi intelektual berkembang di kedua dayah ini pada masa silam dan masa sekarang dapat terungkap.

Penelitian ini diharapkan dapat memberi manfaat kepada para ilmuwan dan masyarakat umum lainnya, serta pihak pemerintah dalam mengambil kebijakannya, karena hasil penelitian ini akan menjadi salah satu bahan yang dapat digunakan sebagai sumber rujukan bagi penelusuran karyakarya ulama yang masih tersimpan di lembagalembaga pendidikan keagamaan khususnya di dayah, di samping sebagai pengayaan bahan bacaan keagamaan bagi lembaga-lembaga pendidikan tersebut. 


\section{Tinjauan Pustaka}

Beberapa penelitian terkait dengan inventarisasi karya ulama sudah pernah dilakukan peneliti, di antaranya adalah kajian yang pernah dilakukan Ulil Abshar Abdallah dan Marzani Anwar tahun 1985. Penelitian mereka terbatas pada beberapa buah kitab berkaitan dengan masalah fiqhiyah saja. Selain itu, Martin van Bruinessen pada tahun 1999 juga (Bruinessen, 1999:131) telah melakukan inventarisasi kitab-kitab kuning terpopuler yang digunakan di pesantren pesantren di tanah air. Fokus kajiannya terbatas pada tingkat penggunaan atau pemakaiannya di pondok pesantren saja. Selanjutnya, Amiq Ahyat tahun 2006, juga telah melakukan penelitian terhadap karya ulama yang khusus terkait dengan naskah tulisan tangan atau ulasan dalam bentuk hasyiah, syarah, terjemahan, khulasah, dan karangan asli, dengan lokasi penelitian di pesantren yang ada di Surabaya.

Namun demikian, sejauh yang diketahui belum ada penelitian khusus tentang karya ulama dalam bentuk naskah tulisan tangan atau ulasan yang dituangkan dalam bentuk hasyiyah, syarah, terjemahan, khulasah, dan karangan asli.

\section{METODE PENELITIAN}

Penelitian ini menggunakan pendekatan filologi dan sejarah, karena karya-karya ulama yang ditemukan semuanya bertuliskan tangan dan sebagian besar sudah berumur cukup tua, yang ditulis sejak abad ke-17 M. Selanjutnya, untuk pendekatan sejarah menjadi penting digunakan dalam penelitian ini untuk mengungkapkan informasi perkembangan tradisi intelektual dari waktu ke waktu.

Data untuk penelitian ini dikumpulkan melalui empat langkah. Pertama, melakukan ekplorasi dengan cara melacak dayah-dayah yang ada di wilayah Aceh melalui browsing. Kedua, mengobservasi data di wilayah Aceh Besar dan Pidie dengan mendatangi dayah-dayah salafi dan mengadakan wawancara dengan pimpinan dayah. Ketiga menginventarisir karya-karya ulama baik yang bertuliskan tangan yang belum diterbitkan ataupun yang diketik dan telah diterbitkan. Keempat, melakukan wawancara dengan para ulama setempat ataupun kaum karabatnya.

Analisis data dalam penelitian ini dilakukan melalui tahap reduksi data, menyajikan data, dan konklusi (verifikasi). Analisis data dilakukan sejak saat pengumpulan data hingga selesai. Data yang terkumpul dan telah direduksi kemudian dideskripsikan, dianalisis isinya, dan dibuat konklusi yang di dalamnya data diverifikasi.

\section{PEMBAHASAN \\ Tradisi dan Aktivitas Penulisan di Aceh}

Sejarah mencatat bahwa para ulama telah mewariskan budaya tulis dari masa ke masa. Tulisantulisan tangan mereka telah tersebar di kalangan rakyat dan dibaca secara meluas. Buah pena mereka telah dijadikan panduan bagi masyarakat Aceh. Untuk hal ini para ulama telah menjadi tonggak pembimbing kehidupan masyarakat Aceh. Mereka diibaratkan sebagai ibu dalam sebuah keluarga (Sabi, 1995:25). Mereka adalah tempat penyelesaian berbagai masalah hidup masyarakat dan yang lebih penting lagi adalah sebagai tempat menimba ilmuilmu agama. Sementara dalam kenegaraan, mereka mendapat posisi yang cukup penting, yaitu sebagai qadi untuk menyelesaikan berbagai masalah yang dihadapi negara. (Fakhriati, 1998:14).

Para ulama di zaman awal Islam dan masa jayanya Aceh didominasi oleh pakar-pakar sufistik. Seperti pada abad ke-17 M, empat tokoh sufi telah memberi sumbangan yang besar dalam berbagai karya mereka yang tidak saja membahas masalah sufi melainkan masalah-masalah keagamaan lainnya sehingga mereka dianggap oleh masyarakat setempat sebagai orang yang bisa menjawab segala masalah agama yang dihadapi masyarakat dan negara. Hamzah Fansuri, adalah salah satu contoh yang tepat disebutkan disini, karena banyak tulisan yang dihasilkannya yang dapat dibaca orang banyak. Syair Perahu adalah salah satu tulisan yang dibaca secara luas, baik pada masanya maupun generasi setelahnya.

Di antara contoh ulama, penulis abad ke- 18 $M$ adalah Faqih Jalaluddin. Ia adalah salah seorang pengikut ajaran Abdurrauf al-Fansuri yang hidup ketika Aceh berada dalam kerajaan Alauddin Syah Johan (1155-1181 H/1742-1767 M). Di antara karya-karyanya yang masih dapat dilacak adalah Hidayatul Awwam diselesaikan pada tahun 1727 $\mathrm{M}$, sebagai karya yang paling awal ditulisnya, berisi penjelasan tentang ajaran agama Islam, Manzalul Ajla Ila Rutbatil A la diselesaikan pada tahun 1739 M, berisi tentang ajaran tarekat Syariyyah, Ujjatul Balagah diselesaikan pada tahun $1745 \mathrm{M}$, berisi pembahasan mengenai masalah fiqhii, dan Safinatul ukkam fi Talkhjil Khiam berisikan uraian tentang Fiqhi (Abdullah, 2004:231-235).

Muhammad Zain, adalah sosok ulama lain yang cukup dikenal dengan tulisan-tulisannya yang 
masih dibaca hingga dewasa ini oleh masyarakat Aceh. Ia merupakan seorang pengkaderan sukses oleh orang tuanya, Faqih Jalaluddin. Di antara karya-karyanya adalah Bidayatul Hidayah yang diselesaikan pada tahun 1757 M. Kitab ini membahas masalah tauhid dan ditulis dalam bahasa Melayu. Karya ini menjadi bacaan dan rujukan kaum Muslimin, tidak hanya di Aceh melainkan di wilayah nusantara pada umumnya hingga sekarang ini. Kitab ini juga kebanyakan digunakan oleh para santri di dayah dan pengajian-pengajian di desa-desa, baik pada tingkat remaja hingga dewasa ini. Karya yang lain adalah Kasyful Kiram yang diselesaikan pada tahun 1757 M (Abdullah, 2004:232).

Teungku di Pulo adalah salah seorang ulama Acehyang hidup pada abadke-19 Myang berdomisili di Teupin Raya telah memanfaatkan dayahnya sebagai tempat penulisan naskah ilmu-ilmu agama. Ia adalah salah seorang ulama yang cukup produktif dalam menulis berbagai ilmu agama untuk murid dan masyarakatnya. Di antara karyanya adalah kitab tafsir, balaghah, nahwu, fiqhi, dan juga tarekat Syattariyyah (Fakhriati, 2010). Peninggalan yang sangat berharga dan masih disimpan keturunannya hingga dewasa ini adalah dua buah tempat tinta untuk menulis yang masing-masing diisi oleh dua tempat meletakkan tinta. Selain itu, Teungku di Pulo memiliki satu meja kecil tempat menulis dalam bentuk yang khas. Meja tersebut terbuat dari kayu. Ia berbentuk empat persegi panjang didisain secara khusus, yaitu bentuk permukaan yang setengah datar dan setengah miring. Dapat diperkirakan bahwa meja ini dipergunakan untuk menulis dalam posisi duduk di atas lantai sehingga sangat tidak mungkin untuk memakai kursi sebagai tempat duduk Teungku di Pulo dalam menulis.

Selain tradisi penulisan, tradisi penyalinan karya-karya ulama juga dilakukan di Aceh dalam rangka menjaga kelestarian peninggalan para ulama yang cukup berharga. Para penyalin naskah telah berusaha menyalin kembali ilmu-ilmu yang sudah diturunkan oleh para guru mereka di Aceh. Mereka menyalin naskah-naskah yang ada dengan penambahan-penambahan dan perubahanperubahan sehingga membuat isi naskah-naskah tersebut bervariasi (Ikram, 2005).

Di Aceh, sebagaimana di daerah lain, wadah yang efektif untuk menyalin kitab sebagai salah satu bentuk transmisi kekayaan intelektual yang dimiliki para ulama Aceh adalah dayah. Di dayah para santri berkumpul dan belajar di bawah bimbingan guru.
Para santri juga menyalin buku-buku para ulama pendahulu yang menjadi warisan budaya intelektual mereka di bawah bimbingan guru mereka. Tradisi penyalinan naskah keagamaan di dayah-dayah seperti ini, berdasarkan kolofon-kolofon beberapa naskah, dapat dikatakan tersebar di berbagai tempat di wilayah Aceh, di antaranya adalah Dayah Lam Ara (Aceh Besar), Dayah Teupin Raya, dan Dayah Tanoh Abee.

Bangunan dayah yang terdiri dari pondokpondok kecil sangat mendukung untuk kepentingan penyalinan kitab-kitab. Pondok ini terbuat dari rumah-rumah kecil yang memuat hanya dua orang santri. Di samping itu, ada juga pondok yang berbentuk rumah panjang yang disekat menjadi beberapa bilik yang terdiri dari dua orang santri untuk setiap bilik. (Ismuha, 1983:19-20). Pondokpondok ini biasanya mengelilingi rumah guru mereka yang disebut dengan teungku.

Selain dayah, masyarakat Aceh kadang menggunakan meunasah (Indonesia: surau) sebagai tempat penyalinan naskah. Meunasah biasa digunakan sebagai tempat berkumpul melaksanakan salat wajib lima waktu dan juga salat tarawih di bulan Ramadhan secara berjamaah. Meunasah juga digunakan sebagai tempat pengajianpengajian yang bersifat sementara untuk anakanak, khususnya anak laki-laki yang berumur enam tahun. Pengajar untuk kegiatan ini adalah peutua meunasah (ketua meunasah yang sekaligus menjaga dan merawat meunasah) (Verheul, 1927; Siegel, 1969:150). Selain itu, meunasah juga digunakan untuk tempat musyawarah masyarakat. Meunasah, tidak seperti dayah yang berfungsi sebagai tempat tinggal para santri dan para ulama, adalah tempat singgah sementara bagi para pengunjungnya. Ia hanya ditempati oleh peutua meunasah yang bertanggungjawab merawatnya. Karena itu, meunasah sedikit sekali dipakai untuk penyalinan naskah, tidak seperti dayah yang ditemukan lebih banyak penyalin naskah (Baihaqi,1983:119-121).

Dalam hal memperkaya khazanah Islam, di samping penyalinan yang dilakukan oleh para penyalin naskah, tradisi penulisan naskahnaskah keagamaan di Aceh ternyata memiliki kecenderungan penulisan tidak mengikuti jalur penulisan karya pengarang sebelumnya. Pengarang lebih condong menciptakan karya tulis sendiri dengan gaya dan ide yang berbeda, meskipun ide inti tetap kembali kepada pengarang sebelumnya (para guru mereka). Kecenderungan ini dapat dikarenakan akibat perubahan sistem budaya yang berlaku dan 
kepentingan yang berbeda. Teungku Muhammad Ali Irsyad Teupin Raya (atau lebih dikenal dengan Abu Maali), misalnya, menulis sejumlah buku atas inisiatif sendiri untuk kepentingan santrinya. Untuk buku panduan para pengikut tarekat, ia menulis buku karangannya sendiri dengan tetap berpegang pada inti ajaran yang sudah ditulis oleh pengarangpengarang sebelumnya (Fakhriati, 2008). Demikian juga dalam pengajaran Qawa id (Tata bahasa Arab), Abu Maali juga menulis buku menurut versinya sendiri, dengan tujuan agar mudah dipahami oleh muridnya.

\section{Profil dan Tradisi Keilmuan di Dayah Tanoh Abee dan Dayah Ruhul Fata Dayah Tanoh Abee}

Zawiyah Tanoh Abee ini adalah salah satu dayah yang tertua yang ada di wilayah Aceh. Dayah ini dibangun pada abad ke-17 M oleh Syekh Nayyan yang memiliki asal usul leluhurnya dari Bagdad. Setelah mendapat izin dari gurunya, Syekh Baba Daud, ia bergerak menuju Seulimum dan mendirikan dayah ini.

Dalam perjalanan sejarahnya, dayah ini telah menjadi panutan masyarakat sekililing dan memiliki sejumlah murid dari berbagai daerah, terutama di sekitar wilayah Aceh. Hal ini dapat dilihat dengan berhasilnya mencetak para ulama terkenal di dayah ini dari periode ke periode.

Dayah ini terletak di Gampong Ujong Mesjid, Gampong Tanoh Abee, Seulimum, Aceh Besar. Dayah ini memiliki sejumlah ruang belajar dan bilikbilik tempat tinggal santri, termasuk juga rumah pemimpin dayah tersebut di dalamnya. Selain itu, di dalam dayah ini terdapat bangunan balee untuk tempat shalat dan tempat pengajian, serta gedung tempat penyimpanan naskah-naskah kuno yang telah dilakukan sejak zaman awal berdirinya dayah ini. Selain yang berlokasi di Gampong Ujong Mesjid, Tanoh Abee yang dekat dengan sungai Seulimum, terdapat juga dayah, yang sekarang sudah menjadi tempat kunjungan dan di sampingnya kuburankuburan ulama dayah Tanoh Abee pada zamanzaman awal, seperti Syekh Nayyan.

Sebagaimana sebuah dayah yang berfungsi untuk mencetak kader-kader ilmuwan yang berbasiskan agama, maka Dayah Tanoh Abee juga cukup memerani hal tersebut. Di dayah ini telah lahir ulama-ulama besar yang telah mampu mengabdikan dirinya untuk agama dan bangsa ini.

Dayah ini adalah dayah salafi. Sistem pembelajaran yang dilakukan di dayah ini juga mengikuti sistem lama atau sistem yang berbentuk salafi. Sistem pengajaran yang diajarkan kepada muridnya mengikuti sistem klasik, yaitu berbentuk halaqah. Setelah belajar mengaji, para santri kembali ke bilik mereka masing-masing untuk mengulangi dan menghafal pelajaran mereka. Di dalam bilikbilik ini juga pada zaman dahulu, tidak untuk masa sekarang, penyalinan naskah pun dilakukan atas perintah guru mereka. Hal ini menjadi salah satu alasan banyaknya naskah tersimpan di dayah ini.

Selain alasan di atas, pengumpulan naskah kuno di dayah ini juga atas usaha dan inisiatif para ulama setempat mempelajari dan mengumpulkan kitab-kitab pada masanya di dayah ini. Bagi mereka yang mumpuni di bidang ilmu agama dan dianggap sudah berhak mendapatkan pengetahuan lebih lanjut, mereka diizinkan berangkat menunju Mekkah untuk mencari ilmu lanjutan. Merupakan sebuah tradisi dari dunia Muslim secara general, terutama Arab yang juga diadopsi oleh orang Indonesia dan Aceh khususnya untuk mengadakan perjalanan ke Timur Tengah dalam mencari guru-guru ahli dalam bidang ilmu agama untuk menyelami pengetahuan agama secara mendalam. (Lihat Azra, 1995).

Selain itu, dayah ini juga memperhatikan masyarakat sekelilingnya. Dayah membuka kesempatan untuk mengajari para anggota masyarakat dengan tidak menginap, melainkan datang harian. Mereka diajarkan biasanya tidak berbarengan dengan murid/santri yang mondok di dayah tersebut. Pelajaran yang diperuntukkan kepada mereka pun tidak setinggi pelajaran para santri pondokan. Mereka mendapatkan pengetahuan agama cukup untuk kepentingan mereka sehari-hari. Bahasa Arab menjadi pelajaran pokok para santri, misalnya, tidak diwajibkan kepada mereka.

Dayah Tanoh Abee telah mencetak para ulama setempat sejak ia berdiri pada abad ke-17 M hingga dewasa ini. Ulama yang pertama sebagai pendirinya adalah Syeikh Nayyan yang berasal dari Bagdad. Pada masa penjajahan Belanda, Teungku Abdul Wahab adalah ulama berikutnya yang terkenal dengan kegigihannya melawan Belanda. Beliau mengajar di dayah dan membela rakyat dan negara di luar dayah untuk bangsa Aceh melawan Belanda. Para ulama di dayah ini, sebagaimana para ulama lain pada umumnya juga melaksanakan perjalanan ke luar negeri, yaitu Timur Tengah. 


\section{Dayah Ruhul Fata}

Dayah Ruhul Fata adalah salah satu Dayah Salafi yang letaknya dekat dengan pasar Seulimum. Dayah ini berlokasi di Jalan Banda Aceh-Medan Km. 42 Seulimum. Kecamatan Seulimum, Kabupaten Aceh Besar. Ia didirikan sejak tahun 1946 oleh Teungku Haji Abdul Wahab.

Teungku Haji Abdul Wahab adalah tokoh ulama yang dikenal cukup gigih dalam memperjuangkan agamanya. Dengan ketekunan menimba ilmu terlebih dahulu di Dayah Mudimesra, ia telah berhasil mendapat tempat terbaik di sisi gurunya (Abon Samalanga), sehingga ia sukses dan diberikan ijazah oleh gurunya. Padahal diketahui bahwa menantu gurunya juga ikut belajar bersamanya, namun gurunya tidak memberikan ijazah kepadanya melainkan lebih mempercayai Teungku Haji Abdul Wahab dengan memberikan izin untuk mengajar ilmu tarekat kepada muridmuridnya dan memberi ijazah tarekat.

Selanjutnya, Teungku Abdul Wahab menjadi ulama yang berhasil mencetak murid-muridnya yang sudah tersebar di berbagai tempat di wilayah Aceh. Para murid ini kemudian membangun dayahdayah lainnya di tempat domisili atau di daerah asal mereka. Antara guru dan murid selalu diciptakan kesinambungan keilmuwan dengan bertemu paling tidak seminggu sekali.

Selain itu, hal yang boleh dikatakan cukup berhasil bagi pendiri dayah ini adalah keberhasilan dalam mendidik keluarga menjadi profesi yang sama dengannya. Pucuk pimpinan dan pengurus dayah ini hingga dewasa ini dipegang oleh anak-anaknya dan hidup berdampingan dengan rukun, damai, dan tentram. Tidak hanya itu, perkembangan dan kejayaan dayah pun semakin mencuat pada masa anak-anaknya memimpin. Anak-anaknya saling bahu membahu memelihara dan membina dayah ini, sehingga dewasa ini santri yang belajar di dayah ini mencapai 1500 jiwa. Untuk para santri lakilaki di pimpin oleh Abon, yaitu anak tertua dari Teungku Haji Muckhtar Luthfi, sedangkan untuk santri perempuan dipimpin oleh Abuya, adik dari Teungku Haji Mukhtar Luthfi.

\section{Ulama yang Menghasilkan Karya}

Pada dua dayah ini dapat diperhatikan bahwa para ulama, terutama pemimpin dayah, cenderung memilih cara berdakwah dan mengajar, yaitu salah satunya dengan menuangkan pikiran, ide, dan pengetahuan mereka dalam bentuk tulisan. Di dayah Tanoh Abee, di antara para ulama yang banyak meninggalkan tulisannya adalah Teungku Abdul Wahab Syekh Muhammad Ali Jughaimān, Muhammad Ali ibn Abdul Muthalib al-Khalidi Sungai Pagoe, Abu Dahlan al-Fairusy, Muhammad Hasan bin Hamzah bin Ismail bin Umar bin Shaleh bin Abdurrahim bin Hafiz bin Nayyan bin Fairuz al-Baghdady Tanoh Abee, Imam Allamah laMuhaqqiq Jalaluddin Muhammad bin Ahmad alMuhlilli asy-Syaf'i, dan Abu Ishal al- 'Āmirah ibn Mu'in Ulee Titi Lamgarut atau Ulee Titi Lambaroe Aceh Besar, Ali Hasan al-Kamrawi, M. Abdul Aziz.

Hal yang sama juga dilakukan di dayah Ruhul Fata. Pemimpin dayah ini juga menulis buku-buku untuk memenuhi kebutuhan santri dan juga masyarakat sekitar. Di antara para teungku yang menjadi penulis adalah Teungku Haji Mukhtar Luthfi bin Syeikh Haji Abdul wahab bin Abbas, Teungku Murtada Lamkunyet, Aceh Besar, Teungku Syarqawi Sibreh, Aceh Besar, Teungku Faisal Jeuned, Teungku Haji 'Abdul Wahab. Di samping menghasilkan karya, mereka juga mengorbit kader-kader ulama dalam hal tulis menulis. Mereka memberi kebebasan kepada santrisantri yang senior untuk menulis buku-buku yang dapat dipergunakan oleh santri dan masyarakat sekitar.

\section{Karya-karya Tulis}

Di antara karya-karya terpenting yang dipelajari di dayah-dayah Aceh, khususnya dayah Tanoh Abee dan Dayah Ruhul Fata adalah kitab Matan Taqrib, Kitab Bajuri, kitab I'anah At-Talibin, dan kitab Mahalli. Kitab-kitab ini menjadi buku wajib bagi santri yang belajar di dayah. Kitab-kitab yang ada di kedua dayah tersebut pada umumnya adalah karangan asli dari penulisnya, meskipun sebagian kecilnya berbentuk syarah dan terjemah.

Kitab-kitab yang berbentuk naskah klasik yang disimpan di Dayah Tanoh Abee tidak untuk digunakan atau dikonsumsi oleh para santrinya, melainkan naskah-naskah tersebut diperlakukan sebagai barang warisan budaya yang perlu dijaga keutuhan fisiknya. Naskah tersebut diletakkan di dalam lemari dan di dalam gedung yang tidak semua orang bisa masuk dan membukanya. Ada dua tempat penyimpanan naskah-naskah tersebut. Pertama naskah-naskah yang terletak di dalam gedung yang diberi nama Perpustakaan Kuno Zawiyah Tanoh Abee, dan kedua naskah yang terletak di dalam lemari di rumah Umi (Umi adalah isteri Abu Dahlan, pemimpin Dayah Tanoh Abee 
yang telah wafat pada tahun 2007. Untuk saat ini, Dayah tersebut berada di bawah pimpinan Umi). Pada umumnya naskah-naskah tersebut sudah di data dan dibuat katalognya. Sementara naskah-naskah yang menjadi sasaran penelitian ini untuk diinvetarisir. Menurut Umi, naskahnaskah yang belum sempat terinvetarisir oleh pihak lain yang pernah masuk ke dayah ini pada tahuntahun sebelumnya. Beliau mengharapkan hasil inventarisasi ini bisa menghasilkan katalog, sebagai bentuk bantuan pemeliharaan dan pelestarian terhadap kitab-kitab tersebut.

Naskah-naskahklasikkeagamaanyangberhasil diinventarisir dalam penelitian ini pada umumnya ditulis oleh para ulama baik dari Dayah Tanoh Abee sendiri maupun ulama Aceh lainnya. Karya-karya tersebut masih dalam bentuk tulisan tangan para ulama tersebut dengan menggunakan tinta warna hitam untuk teks pada umumnya dan tinta merah untuk kata-kata tertentu yang mengandung makna khusus dan penting menurut si penulis. Alas kertas yang digunakan untuk menulis teks naskah-naskah klasik keagamaan tersebut pada umumnya adalah kertas Eropa yang sebagian menggunakan cap air (watermark) dan cap tandingan (countermark). Hal ini menunjukkan bahwa teks naskah-naskah klasik tersebut ditulis pada umumnya pada abad ke-17 M sampai 19 M. Meskipun demikian, ditemukan naskah yang teksnya ditulis di atas kertas bergaris yang diproduksi pada akhir abad ke-19 M dan abad ke-20 M, namun tidak banyak.

Sedangkan kitab-kitab yang diproduksi di Dayah Ruhul Fata belum berupa naskah klasik, karena waktu penulisannya masih belum lama, yaitu di abad ke-20 M sesuai dengan tahun berdirinya dayah tersebut pada tahun $1946 \mathrm{M}$. Kitab-kitab tersebut ditulis dengan tangan oleh para ulama setempat di atas kertas bergaris dan menggunakan tinta warna hitam, biru dan hijau. Kecendrungan penulisan kitab di dayah ini adalah untuk membantu dan memudahkan para santri dan masyarakat sekeliling dalam memahami hal-hal keagamaan, seperti pelaksanaan manasik haji dan umrah, tata cara memahami bahasa Arab dalam bahasa Aceh, terjemahan bahasa Aceh terhadap buku tauhid Aqidatul Awwam, doa-doa yang perlu dibaca sehari-hari, dan buku pengamalan tarekat.

Memperhatikan kepada jenis karya ulama yang ada di kedua dayah ini, kebanyakan para ulama setempat lebih senang menulis dengan menuangkan ide dan pemikirannya sendiri dibandingkan dengan jumlah bentuk karya terjemahan terhadap kitab tertentu, seperti terjemahan atas kitab Jauharut Tauhid, Syarah, dan Mukhtasar, yang jumlahnya lebih sedikit dibandingkan dengan naskah karangan langsung dan asli dari penulisnya. Hal ini menunjukkan bahwa ulama Aceh, baik dalam sejarah maupun ulama dewasa ini memiliki kegemaran menulis dalam intensitas yang lebih tinggi. Kenyataan ini juga menepis anggapan yang pernah dikembangkan oleh Snouck Hurgronje bahwa orang Nusantara termasuk Aceh lebih suka berbicara dari pada menulis (Hurgronje, jilid 1, 1997: 10-14).

Dari sisi isi, kitab-kitab yang ada di dua dayah tersebut lebih banyak ditemukan kitab fiqih beraliran mazhab Syafii. Sebagaimana di dayah dan masyarakat umumnya di Aceh, mereka cendrung menganut ajaran Syafii dalam melaksanakan ketentuan dan aturan-aturan agama mereka, meskipun tidak bisa dihindari aliran mazhab lain seperti mazhab Hanafi yang mengarah kepada syiah juga masih didapat dalam tradisi mereka. Tradisi melebihkan hari Asyura merupakan salah satu contoh yang masih dilakukan oleh masyarakat Aceh pada umumnya termasuk di dayah juga.

Memperhatikan kepada karya tasawuf yang dipakai dan diamalkan di Dayah Tanoh Abee, sebagian kitab berisi ajaran Syattariyah yang ditulis Abuddrauf al-Fansuri. Bahkan karya-karya Abdurrauf al-Fansuri pun masih disimpan di dayah ini, seperti Tanbih al-Masyi versi Tanoh Abee. Versi ini berbeda dengan versi-versi yang disimpan di tempat lain, seperti naskah Tanbih al-Masyi yang disimpan di Perpustakaan Nasional. Dalam naskah versi Tanoh Abee ini ditemukan adanya penambahan satu halaman pada halaman pembuka naskah ini. Halaman ini memberi informasi tentang keutuhan pendirian Abdurrauf dalam ajaran tarekat yang dianutnya. (Fakhriati, 2008:50-51).

Sementara sebagian lainnya, kitab-kitab tasawuf berisi ajaran Syattariyah juga mengacu kepada ajaran Abdurrauf al-Fansuri. Pemimpin Dayah Tanoh Abee sendiri, Teungku Muhammad Ali dan Abu Dahlan juga menulis tentang caracara melaksanakan tarekat Syattariyah dan silsilah tarikat.

Demikian juga dengan Dayah Ruhul Fata yang lebih muda umurnya dibandingkan dengan Dayah Tanoh Abee, karya-karya yang ada lebih mengarah kepada tasawuf dan Tauhid. Di antara karya tersebut adalah Hzihi arqah Syatariyah wa amadiyyah ditulis oleh Teungku Mukhtar 
Luthfi. Buku ini berisi uraian tentang cara-cara yang harus diperhatikan oleh orang yang hendak berkenan masuk tarikat dan segala hal yang perlu dilaksanakan ketika berada dalam tarikat. Buku ini juga dilengkapi dengan doa-doa yang harus dibaca oleh orang tarikat dan mengirim doa kepada guruguru yang ada dalam silsilah tarikat. Kitab Hzihi arqah Khalwatiyyah ditulis oleh Teungku Mukhtar Luthfi. Buku ini berisi uraian tentang cara-cara yang harus diperhatikan oleh orang yang hendak masuk tarikat dan segala hal yang perlu dilaksanakan ketika berada dalam tarikat. Buku ini diawali penjelasannya dengan pengertian dari tarikat Khalwatiyyah dan kelakuan murid terhadap guru, begitu juga sebaliknya. Kitab ini juga dilengkapi dengan pembacaan doa oleh pengikut tarikat dan pengiriman doa kepada guru-guru silsilah mereka.

Sementara kitab tauhid adalah seperti kitab Nazam Lam Lumpoe yang ditulis oleh Teungku Murtada. Buku ini berisi uraian tentang perlunya memahami ketauhidan dan mengamalkannya. Dikatakan oleh pengarang bahwa Syekh Ahmad Marzuki bermimpi menjumpai Rasulullah saw. Di dalam mimpi, ia diajarkan tentang nazam tauhid, sehingga syekh kemudian mencatat ulang isi mimpi tersebut ketika ia bangun, dan diberi nama catatannya dengan Aqdatul Awwam. Pengarang buku ini kemudian mempunyai inisiatif untuk menyusun kembali catatan tersebut ke dalam bahasa Aceh agar mudah dipahami oleh masyarakat Aceh pada umumnya.

Karya-karya tasawuf tersebut di atas memperlihatkan kecenderungan kedua dayah tersebut dalam menganut ajaran tarekat. Kedua dayah ini mengamalkan tarekat yang sama, yaitu tarekat Syattariyah, namun tempat pengambilannya berbeda. Tarekat Syattariyah Dayah Tanoh Abee berasal dari leluhurnya sampai ke Syekh Nayyan, pendiri dayah ini, dan bahkan Syekh Nayyan sendiri adalah murid dari Baba Daud, yaitu murid langsung dari Abdurrauf al-Fansuri. Sementara tarekat Syattariyah Dayah Ruhul Fata tidak memiliki hubungan dengan Dayah Tanoh Abee, meski dalam satu Kabupaten. Teungku Abdul Wahab, pemimpin dayah ini, langsung diberikan ijazah dari Abon (pemimpin) Dayah Samalanga, Aceh Utara. Silsilah yang digunakan juga tidak melalui Abdurrauf alFansuri, melainkan langsung kepada Syekh As'ad dan al-Qusyasyi. Perubahan ini telah terjadi sejak abad ke-19 M. (baca Fakhriati, 2008:201).

Selain itu, kecenderungan banyaknya kajian ilmu agama ke dalam bidang tasawuf juga menjadi relevan untuk tingkat dayah, karena pendidikan tingkat tinggi untuk keagamaan adalah tempatnya di dayah. Diketahui bahwa amalan setelah melaksanakan syariat adalah hakikat yang termuat di dalam tasawuf. Sementara dalam masyarakat umum, kitab yang paling banyak digunakan adalah kitab fiqhi (Baca Fakhriati, 2010: 31-46; dan Oman Fathurrahman dan Munawar Holil, 2007).

Adapun bahasa dan aksara yang paling dominan digunakan di dalam penulisan karyakarya ulama di dua dayah ini adalah Bahasa Melayu dengan aksara Jawi. Hal ini sangat beralasan, karena Aceh merupakan bagian dari wilayah rumpun Melayu, meskipun ia memiliki bahasa sendiri, yaitu bahasa Aceh. Selain itu, perlu dipahami juga bahwa wilayah geografis Aceh terdiri dari beberapa suku, selain suku Aceh, yaitu suku Tamiang, Gayo, dan Minang. Karena itu, tidak heran bila karya tulis pun banyak menggunakan Bahasa Melayu. Selain itu, dominannya bahasa Melayu juga dapat mengindikasikan bahwa karya-karya ulama tersebut diperuntukkan untuk masyarakat Aceh secara luas, dan nusantara secara umum, sehingga bisa dibaca, tidak hanya oleh mereka yang bisa bahasa Aceh, melainkan lebih dari itu, yaitu mencakup wilayah nusantara.

\section{Kesinambungan Penulisan dari Periode ke Periode}

Telah terjadi kesinambungan penulisan karya-karya ulama dari periode ke periode bila memperhatikan dari karya-karya yang terdapat di dua dayah ini. Di Dayah Tanoh Abee ini ditemukan karya-karya abad ke-17 M, di antaranya adalah karya Abdurrauf al-Fansuri, Ar-Raniri, Hamzah Fansuri, dan Syamsuddin As-Sumatrani. Kemudian dilanjutkan dengan abad ke $18 \mathrm{M}$, seperti karangan Faqih Jalaluddin. Sementara abad ke-19 M, dan 20 $\mathrm{M}$ dapat dilihat karya para pemimpin dayah ini seperti karya Teungku Abdul Wahab dan Teungku Muhammad Ali serta Abu Dahlan. Para pemimpin dayah ini terus memelihara dan menjaga kejayaan dayah dengan pengajaran melalui tulisan tangan.

Dayah Ruhul Fata yang muncul di abad ke-20 $M$ juga telah menghasilkan karya-karya para ulama setempat, meskipun tidak sebanyak Dayah Tanoh Abee. Dayah ini sudah memproduksi kitab sejak tahun 1995, yaitu karya yang berjudul Manasik Haji wa 'Umrah ditulis oleh Teungku Luthfi sebagai pimpinan Dayah ini. Penulisan karya-karya terus berlanjut hingga sekarang. Tulisan yang terakhir 
yang dapat ditelusuri adalah Isyarat yang ditulis oleh Teungku Murtada, seorang murid yang sudah berhasil didik di dayah ini dan telah membangun dayahnya sendiri di dekat dayah ini. Kitab ini selesai ditulis pada tahun 2009.

Penulisan yang tidak pernah putus untuk menghasilkan karya-karya yang bermanfaat untuk umat, baik untuk kepentingan para santri maupun untuk masyarakat pada umumnya menunjukkan keaktifan para ulama setempat khususnya dan Aceh pada umumnya dalam menuangkan ilmu mereka dalam bentuk tulisan. Tidak bisa dipungkiri bahwa para ulama masa lampau lebih banyak dalam menulis dibandingkan dengan para ulama dewasa ini. Kemajuan teknologi terutama dalam memperbanyak buku-buku masing sangat jarang dan bahkan hampir tidak, menjadi salah satu alasan yang sangat penting banyaknya penulis dan penyalin di masa lampau dibandingkan dengan masa sekarang. Selain itu, kebanyakan para ulama dapat berkomunikasi langsung dengan para ulama lainnya di luar daerah dan negeri dengan berkunjung lebih lama di Haramun. Merupakan sebuah trend bagi para pribumi yang memiliki kemampuan pengetahuan dan keuangan untuk melaksanakan ibadah haji dan mencari ilmu ke Timur Tengah dalam waktu yang relatif lama.

\section{PENUTUP}

Penelitian terhadap karya-karya ulama yang ada di Dayah Tanoh Abee dan Dayah Ruhul Fata, Aceh Besar ditemukan bahwa para ulama masa lampau dan sekarang telah berhasil menulis dan menyalin kitab-kitab keagamaan untuk umatnya dengan bahasa dominan Melayu dan aksara Jawi sehingga mudah dibaca dan diamalkan isinya oleh si pembaca dari berbagai khalayak. Para ulama ini lebih banyak menulis karangan sendiri dibandingkan dengan menerjemahkan atau mensyarah atau membuat khulasah. Hal ini menunjukkan bahwa tradisi intelektual di Aceh khususnya di dua dayah ini lebih kreatif dan dinamis dalam menuangkan ide-ide dan pikiran mereka ke dalam tulisan mereka dengan merujuk kepada tulisan guru-guru dan ulama ahli di bidang ilmunya, terutama para ulama Timur Tengah.

Sebagaimana karya-karya ulama lainnya, kitab-kitab di dua dayah ini merupakan karyakarya keislaman yang tidak bisa dipisahkan satu sama lainnya dengan karya Islam lainnya secara keseluruhan. Dua dayah ini mengadopsi tradisi
Islam secara keseluruhan di samping unsur-unsur lokal juga terserap di dalamnya.

Naskah-naskah kuno yang tersimpan di dayah Tanoh Abee pada umumnya ditulis dengan mengikuti kaedah-kaedah yang terdapat dalam naskah yang diproduksi di Arab. Dalam naskahnaskah tersebut, penulis sering menggunakan rujukan kepada para ulama di dunia Islam. Dalam Tanbih al-Masyi yang tersimpan di Tanoh Abee, misalnya, Abdurrauf al-Fansuri sebagai pengarangnya menguatkan tulisannya dengan merujuk kepada ulama Timur Tengah.

Sistem penulisan dalam karya-karya yang terdapat di dua dayah ini hampir seluruhnya mengikuti tata cara penulisan naskah Arab yang ada di Timur Tengah. Tata tulis dengan menggunakan kata alihan, rubrikasi, penggunaan kata singkatan, sampai kepada kolofon sepenuhnya mengadopsi model yang ditawarkan dalam naskah Arab tersebut.

Demikian juga untuk naskah-naskah yang beriluminasi, ditemukan bahwa iluminasi pada halaman awal naskah hanya terletak bagian atasnya dengan khas bunga sulur. Iluminasi seperti ini juga berlaku untuk naskah-naskah Islam lainnya yang terdapat di berbagai negara Islam, seperti Turki, India, dan Persia. Perbedaannya terletak pada motif yang digunakan yang menunjukkan kekhasan wilayah masing-masing. Untuk naskah kuno di dayah Tanoh Abee, motif yang digunakan adalah berbentuk tali dililit secara bersilang dan bunga sulur dengan warna yang dominan hitam, merah, dan putih.

Sama halnya dengan karya yang ditulis pada masa yang relatif tidak lama, karya-karya/Ruhul Fata mengindikasikan dirinya sebagai bagian dari karyakarya keislamannya. Yang membedakan mereka hanya dalam kekhasan mereka menggunakan bahasa bahasa daerah. Selain itu, karena mereka sudah dipengaruhi oleh gaya penulisan modern, dalam membuat rujukan sudah mulai menggunakan footnote, meskipun sebagian kitab lainnya masih menggunakan innote sebagaimana kitab Islam lainnya pada masa klasik.

Diketahui bahwa karya ulama Aceh yang tersimpan di Tanoh Abee berupa naskah klasik keagamaan sangat sulit untuk dapat mengaksesnya. Pendekatan dan penyuluhan terkait masa depan naskah klasik perlu ditingkatkan intensitasnya. Selanjutnya, agar wujud karya-karya ulama ini tetap hadir dan dapat dinikmati oleh pembacanya, maka alih media sangat perlu dilakukan secepatnya untuk menyelamatkan dari kerusakan, kehancuran, dan 
kehilangan yang disebabkan oleh man-made dan natural disaster.

\section{UCAPAN TERIMA KASIH}

Penulis menyampaikan terima kasih kepada redaksi jurnal Al-Qalam yang telah memuat tulisan ini. Ucapan terima kasih juga penulis sampaikan kepada seluruh informan pada saat penelitian ini di adakan, tulisan ini tidak akan pernah ada tanpa bantuan para informan dan pemilik naskah. Semoga usaha dan upaya kita bernilai ibadah di sisi-Nya.

\section{DAFTAR PUSTAKA}

Abdullah, Shaghir Wan. 2004, Al-Ma'rifah: Pelbagai Aspek Tasawuf di Nusantara. jilid 1 dan 2. Kualalumpur: Khazanah Fathaniyah.

Azra, Azyumardi. 1995. Jaringan Ulama Timur Tengah dan Kepulauan Nusantara Abad XVII dan XVIII. Bandung: Mizan.

Baihaqi. 1983. "Ulama dan Madrasah di Aceh". dalam Agama dan Perubahan Sosial. diedit oleh Taufik Abdullah. Jakarta: Penerbit CV Rajawali.

Bruinessen, Martin Van. 1999. Kitab Kuning, Pesantren, dan Tarekat, Bandung: Mizan.

Fakhriati. 1998, Sufism and Jihad: The Role of Sufism in Jihad against the Dutch in Acheh in the
Late $19^{\text {th }}$ and Early $20^{\text {th }}$ Centuries. Leiden University: Thesis.

-------. 2008. Menelusuri Tarekat Syattariyah lewat naskah. Balitbang dan Diklat Kementerian Agama RI.

------. 2010, 'New Light on the Life and Work of Teungku di Pulo: An Achehnese Intellectual in the Late $19^{\text {th }}$ and Early $20^{\text {th }}$ Centuries' dalam Jurnal Miqot. IAIN Sumatera Utara Press.

--------. 2010, An Overwhelming Heritage of Manuscripts In Pidie And Aceh Besar Regencies. dalam Jurnal Lektur Keagaman.

Hurgronje, Snouck. C. 1997. Aceh: Rakyat dan Adat Istiadatnya. 2 Jilid. Jakarta: INIS.

Ikram, Achadiati. 2005, Ciri dan Karakteristik Naskah Nusantara, Makalah dipresentasikan pada Pelatihan Konservasi Naskah Kuno, Arsip, dan Dokumen. Jakarta, 25-27 Mei 2005.

Ismuha. 1983. "Ulama Aceh dalam Perspektif Sejarah", dalam Agama dan Perubahan Sosial, diedit oleh Taufik Abdullah. Jakarta: Penerbit CV Rajawali.

Sabi, Yusny. 1995. Islam and Social Change: The Role of the Ulama in Achehnese Society, Disertasi.

Siegel, James, T. 1969. The Rope of God. Los Angeles: University of California Press. 